\title{
STAN KLĘSKI ŻYWIOŁOWEJ JAKO PRZEDMIOT AKTYWNOŚCI POSELSKIEJ W LATACH 2005-2019
}

\author{
THE STATE OF NATURAL DISASTERS AS A SUBJECT OF \\ PARLIAMENTARY ACTIVITY IN THE YEARS 2005-2019
}

Karol Piękoś*

\begin{abstract}
ABSTRAKT
Konstytucja Rzeczypospolitej Polskiej z 2 kwietnia 1997 r. stworzyła możliwość wprowadzenia trzech odmiennych stanów nadzwyczajnych w sytuacji szczególnych zagrożeń. Specjalne przepisy dotyczące stanów nadzwyczajnych zostały określone w trzech odrębnych ustawach, które zostały przyjęte w 2002 r. W latach 2005-2019 w Polsce wystąpiły liczne zdarzenia, które media określały jako klęski żywiołowe. Pomimo że regulacje ustawowe obowiązują od 2002 r. (Dz.U. 2002 nr 62 poz. 558), w Trzeciej Rzeczypospolitej nigdy nie wprowadzono stanu nadzwyczajnego. Posłowie w ramach swojej aktywności parlamentarnej kierowali na przestrzeni V,VI, VII i VIII kadencji zapytania i interpelacje w tej sprawie. Analiza aktywności poselskich związanych ze stanem klęski żywiołowej może być pomocna przy próbie identyfikacji sposobu postrzegania tego stanu nadzwyczajnego przez polityków, a to z kolei
\end{abstract}

\begin{abstract}
The Constitution of the Republic of Poland of 2 April 1997 created the possibility to introduce three different states of emergency in situations of special threat. Special provisions for states of emergency were set out in three separate laws, which were adopted in 2002. Between 2005 and 2019, Poland experienced numerous incidents that the media described as natural disasters. Although the statutory regulations have been in force since 2002 (JoL 2002 No. 62 item 558), a State of Emergency was never introduced in the Third Polish Republic. Within the framework of their parliamentary activity, Deputies during the $5^{\text {th }}, 6^{\text {th }}, 7^{\text {th }}$ and $8^{\text {th }}$ parliamentary terms submitted enquiries and interpellations on this issue. An analysis of parliamentary activities related to the State of Natural Disaster may be helpful in trying to identify the way this State of Emergency is perceived by politicians, which in turn will make
\end{abstract}

* Uniwersytet Rzeszowski, Instytut Nauk o Polityce. 
pozwoli ustalić przyczyny nieposługiwania się tym instrumentem prawnym przez rządzących.

Słowa kluczowe: stan nadzwyczajny; Polska; Sejm; stan klęski żywiołowej; aktywność poselska it possible to determine the reasons why this legal instrument is not used by those in power.

Keywords: State of Emergency; Poland; Sejm; State of Natural Disaster; parliamentary activity

\section{WSTĘP}

Stanom nadzwyczajnym został poświęcony XI rozdział Konstytucji RP. Ustawodawca konstytucyjny wyodrębnił następujące stany nadzwyczajne: stan wojenny, stan wyjątkowy i stan klęski żywiołowej. W przypadku, gdy zwykłe środki konstytucyjne nie są wystarczające, może zostać wprowadzony odpowiedni stan nadzwyczajny. Przyjęte rozwiązania muszą odpowiadać stopniowi zagrożenia, a ich wykorzystanie powinno zmierzać do jak najszybszego przywrócenia normalnego funkcjonowania państwa (Konstytucja Rzeczypospolitej Polskiej z dnia 2 kwietnia 1997 r.).

W analizowanym okresie nie odnotowano ani jednego przypadku wprowadzenia stanu nadzwyczajnego. O ile nie budzi to zdziwienia w przypadku stanu wojennego i stanu wyjątkowego, to inaczej jest w przypadku stanu klęski żywiołowej. Wskazuje na to aktywność poselska, mająca na celu przekonanie członków Radt Ministrów do wprowadzenia takiego stanu, wobec oczywistego wystąpienia ustawowych przesłanek.

Posłowie na Sejm RP zgodnie z art. 191 Regulaminu Sejmu RP mogą występować z interpelacjami, wnioskami o przedstawienie informacji bieżących, zapytaniami poselskimi i pytaniami w sprawach bieżących, które kieruje się do członków Rady Ministrów (Uchwała Sejmu Rzeczypospolitej Polskiej z dnia 30 lipca 1992 r. - Regulamin Sejmu Rzeczypospolitej Polskiej). W trakcie VIII kadencji Sejmu zgłoszono 34043 interpelacje, 9955 zapytań poselskich oraz 835 pytań w sprawach bieżących (Prace Sejmu).

$\mathrm{W}$ artykule objęto badaniem wszystkie podejmowane przez posłów inicjatywy, tj. interpelacje oraz zapytania poselskie w trakcie: V, VI, VII i VIII kadencji, dotyczące stanu klęski żywiołowej. W ramach badań dokonano analizy tych interpelacji i zapytań posłów w których: 1) pytano o możliwość wprowadzenia stanu klęski żywiołowej; 2) postulowano podjęcie takiej inicjatywy; 3) dopytywano o przyczyny niewprowadzenia tego stanu nadzwyczajnego w przypadku zdarzeń mających znamiona klęski żywiołowej. Częstą praktyką jest kierowanie przez tych samych posłów kilku interpelacji i zapytań w tej samej sprawie. $\mathrm{Na}$ 
potrzeby artykułu pominięto inicjatywy, które już wcześniej były przedmiotem indywidualnej aktywności tego samego parlamentarzysty.

Celem artykułu była weryfikacja hipotezy badawczej, która zakłada, że posłowie ugrupowań opozycyjnych częściej występują z postulatem wprowadzenia stanu klęski żywiołowej niż posłowie będący członkami ugrupowań sprawujących władzę. W toku prac postawiono następujące pytania badawcze: 1) w przypadku jakich zdarzeń pojawiały się inicjatywy zmierzające do wprowadzenia stanu klęski żywiołowej? 2) w jaki sposób argumentowano niewprowadzenie stanu klęski żywiołowej? 3) czy stan klęski żywiołowej był adekwatnym stanem nadzwyczajnym do sytuacji, których poselskie inicjatywy dotyczyły?

W artykule wykorzystano metodę porównawczą dla wskazania podobieństw i różnic badanych sytuacji oraz wynikających $\mathrm{z}$ nich inicjatyw poselskich. W prowadzonych badaniach posłużono się również analizą instytucjonalno-prawną, za sprawą której przeanalizowano obowiązujące normy prawne i wynikające z nich możliwości podjęcia działań adekwatnych do danych sytuacji (Chodubski, 2004, ss. 125-126). W celu zbadania aktywności poselskiej we wskazanym zakresie dokonano przeglądu i analizy działań parlamentarzystów w latach 2005-2019.

\section{STAN KLĘSKI ŻYWIOŁOWEJ W POLSKIEJ KONSTRUKCJI STANÓW NADZWYCZAJNYCH}

Od początku XXI w. w Polsce miały miejsce liczne zdarzenia, które w skali lokalnej, regionalnej i ogólnopolskiej określano mianem klęski żywiołowej. Przyczyną tych zjawisk były katastrofy naturalne, m.in. powodzie, wichury, epidemie oraz epizootie $^{1}$. Zgodnie z obowiązującymi przepisami stan klęski żywiołowej może być wprowadzony na okres nie dłuższy niż 30 dni na wybranej części terytorium lub w całym państwie (Kurzępa, 2017, s. 146).

Stan klęski żywiołowej może zostać przedłużony na czas oznaczony za sprawą rozporządzenia Rady Ministrów. Zgodę w tej sprawie musi wyrazić Sejm RP (Dz.U. 2017 poz. 1897). Decyzję o wprowadzeniu stanu klęski żywiołowej podejmuje Rada Ministrów, która posiada uprawnienia do samodzielnego zainicjowania działań lub na wniosek właściwego wojewody. Wprowadzenie

1 Epizootią określa się występowanie choroby zakaźnej wśród zwierząt na danym terenie w zdecydowanie większej ilości niż w latach poprzednich. 
stanu klęski żywiołowej może nastąpić w celu zapobieżenia lub usunięcia skutków katastrof naturalnych i awarii technicznych. Sejm RP posiada ograniczone możliwości w zakresie kontroli decyzji o wprowadzeniu stanu klęski żywiołowej, natomiast zgoda posłów wymagana jest w przypadku przedłużenia tego stanu nadzwyczajnego (Prokop, 2005, ss. 115-116).

\section{WYBRANE INICJATYWY POSELSKIE DOTYCZACEE STANU KLĘSKI ŻYWIOŁOWEJ W OKRESIE V KADENCJI SEJMU RP}

W trakcie V kadencji Sejmu RP trwającej od 19 października 2005 r. do 4 listopada 2007 r., w Polsce rządziła koalicja trzech ugrupowań: Prawo i Sprawiedliwość (PiS), Liga Polskich Rodzin (LPR) oraz Samoobrona RP. W czasie rządów koalicji pod przewodnictwem PiS pojawiło się 8 inicjatyw związanych ze stanem klęski żywiołowej. W $2006 \mathrm{r}$. miała miejsce dotkliwa susza, która wyrządziła straty szacowane na 6,1 mld zł. O skali problemu świadczy również liczba interpelacji i zapytań poselskich, które dotyczyły tej sprawy (Pomoc dla gospodarstw rolnych $w$ celu złagodzenia skutków suszy).

$\mathrm{Na} 8$ wymienionych w tabeli aktywności 5 dotyczyło problemu suszy z $2006 \mathrm{r}$. Posłowie zwracali uwagę na poniesione straty oraz trudną sytuację w rolnictwie, poseł Platformy Obywatelskiej (PO) Bogdan Bojko postulował wprowadzenie

Tabela 1. Poselskie inicjatywy dotyczące stanu klęski żywiołowej w V kadencji Sejmu RP

\begin{tabular}{|c|c|c|c|c|}
\hline $\begin{array}{c}\text { Data } \\
\text { aktywności }\end{array}$ & Rodzaj zdarzenia & $\begin{array}{c}\text { Poseł podejmujący } \\
\text { inicjatywę }\end{array}$ & Ugrupowanie & Kategoria \\
\hline 19.07 .2006 & susza & Bogdan Bojko & PO & Interpelacja \\
\hline 19.07 .2006 & susza & Bogusław Wontor & SLD & Interpelacja \\
\hline 19.07 .2006 & susza & Henryk Smolarz & PSL & Interpelacja \\
\hline 21.08 .2006 & susza/powódź & Jerzy Szmajdziński & SLD & Zapytanie \\
\hline 29.08 .2006 & powódź/susza/nawałnica & Wojciech Wilk & PO & Interpelacja \\
\hline 23.08 .2006 & powódź & Dorota Sawicka & PO & Zapytanie \\
\hline 08.09 .2006 & susza/gwałtowne opady & Stanisław Wziątek & SLD & Interpelacja \\
\hline 04.05 .2007 & przymrozki & Adam Szejnfeld & PO & Zapytanie \\
\hline
\end{tabular}

Źródło: Opracowanie własne na podstawie danych pochodzących ze strony internetowej Sejmu Rzeczypospolitej Polskiej. 
stanu klęski żywiołowej na obszarze województwa lubuskiego, podobnie jak poseł Sojuszu Lewicy Demokratycznej (SLD) Bogusław Wontor. W odpowiedzi Sekretarza Stanu Marka Zagórskiego podkreślano, że wprowadzenie stanu klęski żywiołowej nie zapewni oczekiwanej przez producentów pomocy. Posłowie Wojciech Wilk (PO), Jerzy Szmajdziński (SLD) oraz Stanisław Wziątek (SLD) zwracali uwagę na wystąpienie kilku niekorzystnych zdarzeń, m.in. powodzi, nawałnic i susz, które spowodowały straty w rolnictwie.

Poseł Adam Szejnfeld (PO) skierował zapytanie w sprawie strat spowodowanych przez przymrozki, do których doszło wiosną 2007 r. Parlamentarzysta PO pytał również o rozmowy ministerstwa Rolnictwa i Rozwoju Wsi z wojewodami w sprawie wprowadzenia stanu klęski żywiołowej na dotkniętych klęską obszarach. W wyniku spadku temperatury zniszczeniu uległ kwiatostan drzew i krzewów owocowych. Z przedstawionych przez Główny Urząd Statystyczny danych wynikało, że w przypadku plantacji moreli i brzoskwiń uszkodzenia dotyczyły do $80 \%$ plantacji (Odpowiedź na zapytanie nr 2715).

Inicjatywy zmierzające do wprowadzenia stanu klęski żywiołowej pojawiały się również ze strony samorządowców. Przykładem jest Starosta Tarnowski Zbigniew Karciński, który do Wojewody Małopolskiego złożył wniosek w tej sprawie (Starosta tarnowski: - Mamy klęskę żywiołową!). Lider Samoobrony Andrzej Lepper zapowiadał, że doraźna pomoc dla rolników może sięgać około $300 \mathrm{mln} \mathrm{zl}$, a jej beneficjentami miało być około 300 tys. gospodarstw (Lepper: Doraźna pomoc dla rolników dotkniętych suszą może sięgnać ok. $300 \mathrm{mln} z$ ) ).

$\mathrm{Z}$ przedstawionych w tabeli danych wynika, że inicjatywy związane ze stanem klęski żywiołowej podejmowali wyłącznie posłowie ugrupowań opozycyjnych. Najczęstszą przyczyną aktywności poselskiej w tym zakresie była klęska suszy.

\section{WYBRANE INICJATYWY POSELSKIE DOTYCZĄCE KLĘSKI ŻYWIOŁOWEJ W VI KADENCJI SEJMU RP}

Przeprowadzone 21 października 2007 r. wybory zmieniły układ sił politycznych w polskim parlamencie. W VI kadencji Sejmu rządy sprawowała koalicja PO oraz Polskiego Stronnictwa Ludowego (PSL) (Borowiec, 2008, s. 43). Posłowie tych ugrupowań najczęściej podejmowali działania w sprawach związanych z możliwością wprowadzenia stanu klęski żywiołowej w poprzedniej kadencji Sejmu RP. W trakcie rządów PO i PSL na obszarze Polski miała miejsce jedna z największych powodzi w dziejach Trzeciej Rzeczypospolitej. Rozmiar katakli- 
Tabela 2. Poselskie inicjatywy dotyczące stanu klęski żywiołowej w VI kadencji Sejmu RP

\begin{tabular}{|c|c|c|c|c|}
\hline $\begin{array}{c}\text { Data } \\
\text { aktywności }\end{array}$ & $\begin{array}{c}\text { Rodzaj } \\
\text { zdarzenia }\end{array}$ & $\begin{array}{c}\text { Poseł podejmujący } \\
\text { inicjatywę }\end{array}$ & Ugrupowanie & Kategoria \\
\hline 03.07 .2008 & susza & Mieczysław Łuczak & PSL & Interpelacja \\
\hline 14.07 .2009 & powódź & Kazimierz Gwiazdowski & PiS & Interpelacja \\
\hline 08.06 .2010 & powódź & Jarosław Zieliński & PiS & Interpelacja \\
\hline 10.05 .2011 & przymrozki & Łukasz Zbonikowski & PiS & Interpelacja \\
\hline 11.05 .2011 & przymrozki & Zbigniew Dolata & PiS & Interpelacja \\
\hline
\end{tabular}

Źródło: Opracowanie własne na podstawie danych pochodzących ze strony internetowej Sejmu Rzeczypospolitej Polskiej.

zmu po raz kolejny zwrócił uwagę na możliwość wprowadzenia w Polsce stanu klęski żywiołowej.

Przedstawione $\mathrm{w}$ tabeli dane ukazują, że w sprawach związanych z wprowadzeniem lub niewprowadzeniem stanu klęski żywiołowej najczęściej interpelowali posłowie partii PiS, która w VI kadencji Sejmu RP znajdowała się w opozycji. Największą katastrofą naturalną w trakcie VI kadencji Sejmu RP była powódź, która wyrządziła straty szacowane na około $12 \mathrm{mld}$ zł (Dziesięć lat po wielkiej powodzi. Inwestycje i działania Wód Polskich). W sprawie powodzi z 2010 r. pojawiły się liczne inicjatywy posłów w postaci zapytań, interpelacji i pytań w sprawach bieżących, natomiast w przypadku interpelacji Jarosława Zielińskiego znalazło się pytanie o przyczynę niewprowadzenia stanu klęski żywiołowej (Interpelacja $n r$ 16330). W odpowiedzi na interpelację nie wskazano wprost na przyczyny takiej decyzji. Odpowiadający Sekretarz Stanu Tomasz Siemoniak (PO) zwracał uwagę na podejmowane przez rząd działania przed i w trakcie powodzi (Odpowiedź na interpelację nr 16330).

W mediach spekulowano, że przyczyną niewprowadzenia stanu klęski żywiołowej były wybory prezydenckie. Pojawiały się opinie wskazujące na niechęć do podjęcia takiej decyzji ze względu na malejące poparcie kandydata PO na urząd Prezydenta RP Bronisława Komorowskiego. Decyzja o wprowadzeniu stanu klęski żywiołowej opóźniłaby planowane na 20 czerwca 2010 r. wybory prezydenckie. Nie było to korzystne rozwiązanie dla PO, gdyż powódź negatywnie wpływała na poparcie dla rządu.

Ówczesny Premier Donald Tusk podkreślał, że państwo radzi sobie z kryzysem i na chwilę obecną nie ma konieczności wprowadzenia stanu nadzwyczaj- 
nego. Premier zaznaczał, że jeżeli będzie taka konieczność, to podejmie decyzję o wprowadzeniu stanu klęski żywiołowej. Sprawa powodzi była jednym z wiodących tematów w trakcie kampanii wyborczej (A. Stankiewicz, P. Śmiłowicz, Kaczyński czy Komorowski, czyli komu pomoże wielka woda).

Pozostałe interpelacje dotyczyły powodzi z 2009 r., suszy i przymrozków. Powódź, do której doszło w 2010 r., była jednym z największych kataklizmów w XXI w na ziemiach polskich pod względem wyrządzonych strat. Pomimo skali zjawiska nie odnotowano wielu przedmiotowych inicjatyw poselskich dotyczących stanu klęski żywiołowej. Niewątpliwie powódź z 2010 r. ożywiła w polskiej debacie publicznej dyskusję na temat stanów nadzwyczajnych.

\section{WYBRANE INICJATYWY POSELSKIE DOTYCZACE STANU KLĘSKI ŻYWIOŁOWEJ W OKRESIE VII KADENCJI SEJMU RP}

W zaplanowanych na 9 października $2011 \mathrm{r}$. wyborach parlamentarnych po raz kolejny najlepszy wynik uzyskała PO, która ponownie wraz z PSL utworzyła wspólny rząd (K. Kowalczyk, L. Hurska-Kowalczyk, 2012, s. 89). W parlamencie swoją reprezentacje posiadały też następujące ugrupowania: PiS, Ruch Palikota oraz SLD.

Dotąd nienotowanym zagrożeniem naturalnym, które mogło być potencjalną przyczyną wprowadzenia stanu klęski żywiołowej, był wirus afrykańskiego pomoru świń (ASF), który rozprzestrzeniał się wśród dzików oraz trzody chlewnej. Pierwszy przypadek ASF stwierdzono na terytorium Polski w lutym 2014 r. Zagrożenie wynikające z epizootii ASF dotyczyło głównie hodowców trzody chlewnej, którzy z powodu rozprzestrzeniania się choroby wśród zwierząt narażeni byli na wysokie straty (Pomór świn w Polsce: Jest tragedia). Problem ASF został dostrzeżony przez polityków, którzy w trakcie obrad parlamentarnych odnosili się do tej kwestii.

Przedstawione zestawienie inicjatyw poselskich z okresu VII kadencji Sejmu RP ukazuje, że najczęściej w sprawie stanu klęski żywiołowej interpelowali posłowie opozycyjnej wówczas partii PiS. W tabeli znalazło się 19 aktywności parlamentarzystów, z których 8 podjętych zostało przez posłów tego ugrupowania. Parlamentarzyści należący do jednej z partii rządzącej w ramach koalicji PO-PSL podjęli tylko 2 takie inicjatywy. Pozostałe przedsięwzięcia wynikały z działalności posłów ugrupowań opozycyjnych lub posłów nienależących do żadnej partii. Najczęstszą przyczyną podejmowanych inicjatyw była susza z 2015 r., która 
Tabela 3. Poselskie inicjatywy dotyczące stanu klęski żywiołowej w okresie VII kadencji Sejmu RP

\begin{tabular}{|c|c|c|c|c|}
\hline $\begin{array}{c}\text { Data } \\
\text { aktywności }\end{array}$ & Rodzaj zdarzenia & $\begin{array}{c}\text { Poseł podejmujący } \\
\text { inicjatywę }\end{array}$ & Ugrupowanie & Kategoria \\
\hline 26.03 .2012 & susza/przymrozki & Anna Bańkowska & SLD & Zapytanie \\
\hline 28.03.2012 & susza/przymrozki & Szymon Giżyński & PiS & Interpelacja \\
\hline 29.03.2012 & przymrozki & Marek Matuszewski & PiS & Interpelacja \\
\hline 22.05 .2012 & przymrozki/susza & Zbigniew Giżyński & PiS & Interpelacja \\
\hline 22.05 .2012 & susza/przymrozki & Iwona Kozłowska & $\mathrm{PO}$ & Zapytanie \\
\hline 05.07 .2012 & $\begin{array}{c}\text { gwałtowne zjawisko } \\
\text { pogodowe }\end{array}$ & Tadeusz Iwiński & SLD & Zapytanie \\
\hline 12.07.2013 & nawałnice & Marek Balt & SLD & Interpelacja \\
\hline 31.07 .2015 & susza & Janusz Dzięcioł & $\begin{array}{c}\text { Brak (klub parla- } \\
\text { mentarny PO) }\end{array}$ & Zapytanie \\
\hline 11.12 .2013 & $\begin{array}{c}\text { susza/przymrozki/ } \\
\text { gwałtowane opady/ } \\
\text { gradobicia }\end{array}$ & $\begin{array}{c}\text { Mieczysław Marcin } \\
\text { Łuczak }\end{array}$ & PSL & Zapytanie \\
\hline 26.05 .2014 & powódź & Jarosław Gowin & PRJG & Interpelacja \\
\hline 14.09 .2014 & susza & Jerzy Wenderlich & SLD & Interpelacja \\
\hline 26.11 .2014 & epizootia & Jarosław Zieliński & PiS & Interpelacja \\
\hline 16.07.2015 & epizootia & Adam Rybakowicz & Twój Ruch & Interpelacja \\
\hline 12.08 .2015 & susza & Marek Matuszewski & PiS & Zapytanie \\
\hline 19.08.2015 & susza & Przemysław Czarnecki & PiS & Interpelacja \\
\hline 20.08 .2015 & susza & Krzysztof Borkowski & PSL & Interpelacja \\
\hline 20.08 .2015 & susza & Jarosław Zieliński & PiS & Interpelacja \\
\hline 25.08 .2015 & susza & Kazimierz Ziobro & Solidarna Polska & Interpelacja \\
\hline 07.09.2015 & susza & Dariusz Piontkowski & PiS & Interpelacja \\
\hline
\end{tabular}

Źródło: Opracowanie własne na podstawie danych pochodzących ze strony internetowej Sejmu Rzeczypospolitej Polskiej.

wyrządziła szkody w rolnictwie szacowane na ponad mld zł (Susza w Polsce. Straty rolników sa już szacowane na 1 mld zł, zagrożone 99 proc. upraw).

O przyczynę niewprowadzenia stanu klęski żywiołowej pytał m.in. poseł Dariusz Piontkowski (PiS). W odpowiedzi na interpelację przedstawiciele rządu stwierdzili: „Ogłoszenie stanu klęski żywiołowej nie stanowi samoistnej, czy nawet dodatkowej, przesłanki do otrzymania nadzwyczajnej pomocy finansowej z budżetu państwa przez poszkodowane podmioty, w tym rolników". Podobnie 
jak w poprzednich latach rząd wskazywał na formy wsparcia przewidziane dla rolników poszkodowanych przez suszę (Odpowiedź na interpelację nr 34515).

Interesującym przypadkiem jest interpelacja posła J. Zielińskiego (PiS), który skierował m.in. pytanie w sprawie rozpatrzenia wniosku Wojewody Podlaskiego o wprowadzenie stanu klęski żywiołowej w związku z ASF. W uzyskanej odpowiedzi poinformowano, że wniosek był przedmiotem prac Rady Ministrów, która poleciła Ministrowi Rolnictwa przygotowanie rozwiązań stosownych do zaistniałej sytuacji (Odpowiedź na interpelację nr 29624).

W przypadku suszy, która również w VII kadencji Sejmu RP była przyczyną wielu interpelacji z pytaniem o wprowadzenie stanu klęski żywiołowej, zwracał się poseł Kazimierz Ziobro z Solidarnej Polski (SP). W odpowiedzi na interpelację wskazano: „Należy również podkreślić, że ogłoszenie stanu klęski żywiołowej nie stanowi samoistnej, czy nawet dodatkowej, przesłanki do otrzymania nadzwyczajnej pomocy finansowej z budżetu państwa przez poszkodowane podmioty, w tym rolników”. W dalszej części podkreślono „Podobnie przepisy innych aktów prawnych określających formy i zasady pomocy dla podmiotów poszkodowanych w wyniku klęsk żywiołowych, nie uzależniają możliwości jej uruchomienia od ogłoszenia stanu nadzwyczajnego" (Odpowiedź na interpelacje $n r$ 34379). Na podstawie tej odpowiedzi można wywnioskować, że udzielanie wsparcia było możliwe bez szczególnych rozwiązań, a co za tym idzie, zwalczanie klęsk żywiołowych zdaniem rządu mogło być dokonywane bez specjalnych rozwiązań konstytucyjnych.

W trakcie VII kadencji Sejmu RP pojawiło się najwięcej inicjatyw spełniających zaproponowane kryteria. Również w trakcie VII kadencji dominującą przyczyną przedmiotowych interpelacji i zapytań poselskich była susza. Ponownie posłowie opozycji częściej interpelowali lub zadawali pytania poselskie w sprawie stanu klęski żywiołowej, co przypominało sytuację z poprzednich kadencji. Zauważyć należy, że im większą siłę w parlamencie stanowi partia opozycyjna, tym więcej takich inicjatyw jest kierowanych do przedstawicieli rządu.

\section{WYBRANE INICJATYWY POSELSKIE DOTYCZACCE STANU KLĘSKI ŻYWIOŁOWEJ W OKRESIE VIII KADENCJI SEJMU RP}

W 2015 r. odbyły się wybory parlamentarne, które zmieniły układ sił w Sejmie. Po trwających przez 8 lat rządach koalicji PO i PSL nastąpiła zmiana władzy, większość w Sejmie uzyskało PiS. Reprezentację w parlamencie posiadały nastę- 
pujące ugrupowania: PiS, PO, PSL, Nowoczesna Ryszarda Petru, Kukiz 15 (Szczepański, 2016, s. 175). W trakcie VIII kadencji parlamentu w Polsce, podobnie jak w poprzednich latach, pojawił się problem suszy. Trudną próbę dla systemu zarządzania kryzysowego w państwie stanowiła nawałnica, która przeszła przez Polskę na przełomie 10 i 11 sierpnia 2017 r. Gwałtowne burze doprowadziły do śmierci 6 osób. W akcję usuwania skutków zdarzenia zaangażowanych było ponad 70 tys. strażaków. Uszkodzeniu uległo ponad 3500 budynków (Ofiary śmiertelne, ranni. Tysiące interwencji i brak pradu. Tragiczny bilans nawałnic).

Wstępne szacunki strat wyrządzonych na obszarze województwa pomorskiego wyniosły $2,7 \mathrm{mld}$ zł. W wyniku gwałtownego zjawiska pogodowego doszło do zniszczeń drzewostanu, uszkodzenia budynków mieszkalnych, strat w infrastrukturze sieciowej, strat w mieniu publicznym i szkód w przedsiębiorstwach (C. Wodzikowski, 2019, s. 55).

Tabela 4. Poselskie inicjatywy dotyczące stanu klęski żywiołowej w VIII kadencji Sejmu RP

\begin{tabular}{|c|c|c|c|c|}
\hline $\begin{array}{c}\text { Data } \\
\text { aktywności }\end{array}$ & Rodzaj zdarzenia & $\begin{array}{c}\text { Poseł podejmujący } \\
\text { inicjatywę }\end{array}$ & Ugrupowanie & Kategoria \\
\hline 19.06 .2018 & susza & Krzysztof Paszyk & PSL & Interpelacja \\
\hline 16.08.2017 & nawałnice & $\begin{array}{c}\text { Grzegorz Furgo } \\
\text { Marta Golbik } \\
\text { Agnieszka Pomaska } \\
\text { Adam Korol }\end{array}$ & $\begin{array}{c}\text { PO } \\
\text { PO } \\
\text { PO }\end{array}$ & Interpelacja \\
\hline 18.08 .2017 & nawałnice & Monika Wielichowska & PO & Interpelacja \\
\hline 17.08 .2017 & nawałnice & Adam Korol & PO & Interpelacja \\
\hline 10.09 .2017 & susza & Zbigniew Ajchler & PO & Interpelacja \\
\hline 10.10 .2017 & powódź & Krzysztof Paszyk & PSL & Interpelacja \\
\hline 06.06 .2018 & susza & Norbert Kaczmarczyk & Kukiz 15* & Interpelacja \\
\hline 21.08 .2018 & susza & Paulina Hennig-Kloska & $\begin{array}{c}\text { Nowoczesna } \\
\text { Ryszarda Petru }\end{array}$ & Interpelacja \\
\hline 30.04 .2019 & susza & Michał Jaros & PO & Interpelacja \\
\hline 24.05 .2019 & powódź & Norbert Kaczmarczyk & Kukiz 15* & Interpelacja \\
\hline
\end{tabular}

* Ruch Kukiz 15 z formalnego punktu widzenia nie był partią polityczną, natomiast działał jak klasyczne ugrupowania polityczne.

Źródło: Opracowanie własne na podstawie danych pochodzących ze strony internetowej Sejmu Rzeczypospolitej Polskiej. 
W sprawie nawałnicy z sierpnia $2017 \mathrm{r}$. interpelujący posłowie pytali m.in. o powód niewprowadzenia stanu klęski żywiołowej. Z odpowiedzi przedstawicieli rządu wynikało, że decyzja była podyktowana brakiem wniosku właściwego wojewody oraz - zdaniem przedstawicieli rządu - sprawnym usuwaniem skutków nawałnic. Rządzący wskazywali również na szereg ograniczeń, jakie towarzyszą wprowadzeniu stanu klęski żywiołowej. Interesujące jest, że w tym przypadku odpowiadał z upoważnienia właściwego ministra Sekretarz Stanu - Jarosław Zieliński (PiS), który w poprzedzających kadencjach trzy razy interpelował w sprawach związanych ze stanem klęski żywiołowej. W interpelacji z 8 czerwca $2010 \mathrm{r}$. J. Zieliński (PiS) pytał o przyczyny niewprowadzenia stanu klęski żywiołowej pomimo istniejących ku temu podstaw (Interpelacja $n r$ 16330).

Poseł Kukiz 15 Norbert Kaczmarczyk w skierowanej do ministra rolnictwa i rozwoju wsi interpelacji wprost pytał o to, czy w związku z suszą zostanie w Polsce wprowadzony stan klęski żywiołowej. W odpowiedzi na interpelację Rafał Romanowski (PiS), podsekretarz stanu w Ministerstwie Rolnictwa i Rozwoju Wsi, podkreślał: „,Biorąc pod uwagę powyższe, suszę można zakwalifikować jako stan klęski żywiołowej”.W dalszej części interpelacji R. Romanowski wskazywał na szereg ograniczeń związanych z wprowadzeniem stanu klęski żywiołowej i to, czy byłby one adekwatne do tej sytuacji. W odpowiedzi podkreślono również, że z powodu wprowadzenia stanu nadzwyczajnego nie mogą odbywać się wybory i referenda. Podobnie jak w poprzednich latach zwracano uwagę na formy wsparcia przewidziane dla poszkodowanych rolników (Odpowiedź na interpelację $n r$ 22820).

Przedstawione w Tabeli 5 dane ukazują diametralną zmianę. W trakcie VIII kadencji Sejmu posłowie PiS nie interpelowali w przedmiotowej sprawie, natomiast znajdujący się od 2015 r. w opozycji posłowie PO i PSL zaczęli wykazywać zdecydowanie większe zaangażowanie w tym obszarze. Aktywność wskazanych ugrupowań w badanym zakresie niewątpliwie była uzależniona od faktu, czy dane ugrupowanie znajduje się w opozycji.

\section{PODSUMOWANIE}

Podjęcie decyzji o wprowadzeniu lub niewprowadzeniu stanu klęski żywiołowej wywołuje wiele emocji w gronie polityków, ekspertów, ale i w społeczeństwie. Z przeprowadzonej analizy wynika, że w Polsce często dochodzi do zdarzeń mających znamiona klęski żywiołowej. $Z$ tego powodu wnioski o wprowadzenie tego 
stanu nadzwyczajnego nie powinny być zaskoczeniem. Ostateczną decyzję w sprawie wprowadzenia stanu klęski żywiołowej podejmuje Rada Ministrów, w związku z tym cały ciężar decyzji spoczywa na ugrupowaniu sprawującym władzę.

Za sprawą zrealizowanych badań dokonano pozytywnej weryfikacji hipotezy badawczej. Przeprowadzona analiza pozwala stwierdzić, że to posłowie opozycji częściej w swoich działaniach poruszają kwestię wprowadzenia stanu klęski żywiołowej. W latach 2005-2019 odnotowano łącznie 42 przedmiotowe inicjatywy, z czego 37 zostało podjętych przez posłów ugrupowań opozycyjnych, natomiast jedną aktywność $\mathrm{w}$ tym obszarze zanotował poseł bez przynależności do żadnego stronnictwa. Tylko 4 inicjatywy były poodejmowane przez parlamentarzystów ze środowisk ugrupowań sprawujących władzę w badanym okresie. W latach 2005-2019 najczęściej przedmiotową aktywność podejmowali posłowie następujących partii politycznych: PiS (12), PO (10), SLD (7) oraz PSL (6). Parlamentarzyści PiS w momencie rządów tej partii podjęli 0 przedmiotowych inicjatyw, PO - 1, PSL - 3. Jedynie parlamentarzyści PSL wykazali taką samą aktywność w okresie, gdy byli częścią opozycji i gdy sprawowali władzę.

$\mathrm{Na}$ podstawie przeprowadzonych analiz możliwe jest udzielenie odpowiedzi na pierwsze z postawionych pytań badawczych. Zdarzeniem, które najczęściej stanowiło przyczynę aktywności poselskich w sprawie stanu klęski żywiołowej, była susza. W przypadku drugiego pytania badawczego konieczne jest udzielenie szerszej odpowiedzi. Rządzący często argumentowali niewprowadzenie stanu klęski żywiołowej koniecznością ograniczania wolności i swobód obywateli, uruchomieniem programów wsparcia oraz faktem, że podjęcie decyzji o wprowadzeniu stanu nadzwyczajnego nie przyczyni się do poprawy sytuacji poszkodowanych osób. Niekiedy w odpowiedzi na poselską interpelację nie odpowiadano jednoznacznie na to pytanie. Należy w tym miejscu podkreślić, że wobec stanów nadzwyczajnych stosuje się szereg zasad, m.in. zasadę proporcjonalności. Wykorzystywanie pełnego katalogu ograniczeń swobód i wolności obywatelskich nie jest konieczne. Decyzja o skali ograniczeń powinna wynikać z analizy sytuacji. Rządzący posiadają taką możliwość, która nie musi być stosowana.

W toku analizy uzyskano również odpowiedź na trzecie pytanie badawcze. Stan klęski żywiołowej był adekwatnym stanem nadzwyczajnym w przypadku podejmowanych przez posłów aktywności. Przesłanki, jakimi są susze, powodzie, przymrozki, epidemie wśród zwierząt oraz gwałtowne zjawiska pogodowe, wpisują się w katalog zdarzeń zawartych w ustawie o stanie klęski żywiołowej.

Za szczególnie niepokojące należy uznać zjawisko wykorzystywania instytucji stanów nadzwyczajnych w bieżącej walce politycznej pomiędzy stroną rządzącą 
a opozycją. Polaryzacja, do której doszło na gruncie polskiej polityki, wiąże się z ideą określaną w politycznej propagandzie mianem ,wojny totalnej”. W ramach próby sił dochodzi do urzeczywistnienia tej koncepcji, która determinuje działania polityków znajdujących sią w obozie władzy, jak i w opozycji (Grabowski, 2018, s. 51).

Na tym etapie rozważań trudno jest prognozować, czy w najbliższych latach przedstawiona tendencja będzie się nadal utrzymywać, czy też ulegnie diametralnej zmianie. Podstawowym problemem wydaje się być brak samokrytyki w środowisku rządzącym oraz niedopuszczanie do wyrażania odmiennego zdania. W trakcie VII kadencji około $25 \%$ aktywności zgłaszali posłowie sprawującej władzę koalicji, a podczas VIII kadencji Sejmu posłowie ze środowiska partii rządzącej nie podejmowali takich aktywności. Postulat wprowadzenia stanu nadzwyczajnego stał się w ostatnich latach domeną opozycji. Aktualnie nie istnieją przesłanki pozwalające na stwierdzenie, że sytuacja w najbliższej przyszłości będzie ulegać zmianie. Z dokonanej analizy wynika, że dla rządzących wizja wprowadzenia stanu klęski żywiołowej jest niemożliwa do realizacji, dlatego posłowie należący do partii sprawujących władzę nie podnoszą tego postulatu. Perspektywa ta jest zupełnie odmienna w przypadku opozycji, która często odwołuje się do możliwości wprowadzenia tego stanu nadzwyczajnego. Niepokojący jest również fakt, że w praktyce doszło do upolitycznienia instytucji stanów nadzwyczajnych, która miała przecież służyć nie politycznym celom, ale obywatelom.

\section{BIBLIOGRAFIA:}

(2006). Lepper: Doraźna pomoc dla rolników dotkniętych susza może sięgnąć ok. $300 \mathrm{mln}$ $z$. Pobrane z: https://www.parkiet.com/artykul/459428.html.

(2006). Starosta tarnowski: - Mamy klęskę żywiołową! Pobrane z: https://classic.wyborcza.pl/archiwumGW/4690082/Starosta-tarnowski----Mamy-kleske-zywiolowa-.

(2015). Susza $w$ Polsce. Straty rolników sa już szacowane na 1 mld zt, zagrożone 99 proc. upraw. Pobrane z: https://www.money.pl/gospodarka/wiadomosci/artykul/ susza-w-polsce-straty-rolnikow-sa-juz,158,0,1899422.html.

(2017). Ofiary śmiertelne, ranni. Tysiace interwencji i brak prąu. Tragiczny bilans nawatnic. Pobrane z: https://tvn24.pl/tvnmeteo/informacje-pogoda/polska,28/ ofiary-smiertelne-ranni-tysiace-interwencji-i-brak-pradu-tragiczny-bilansnawalnic,238153,1,0.html.

Borowiec, P. (2008). Uwarunkowania, przebieg i wyniki wyborów parlamentarnych 2007 roku. W: K. Pokorna-Ignatowicz (red.). Wybory parlamentarne 2007 - Media w kampanii wyborczej, (ss. 13-45). Kraków: Wyd. Oficyna Wydawnicza AFM. 
Chodubski, A. J. (2004). Wstęp do badań politologicznych. Gdańsk: Wyd. Uniwersytetu Gdańskiego.

Grabowski, R. (2018). Refleksje nad polskim modelem parlamentaryzmu. Przeglad Prawa Konstytucyjnego, 5(45), 49-59. DOI 10.15804/ppk.2018.05.03.

(2007). Pomoc dla gospodarstw rolnych w celu złagodzenia skutków suszy. Pobrane z: https://ec.europa.eu/competition/state_aid/cases/216537/216537_651503_23_2. pdf.

Kowalczyk, K., Hurska-Kowalczyk, L. (2012). Kampania Platformy Obywatelskiej w wyborach parlamentarnych w 2011 roku - strategia, taktyka, rezultaty. Athenaeum, 35, 78-92.

Kurzępa, E. (2017). Stany nadzwyczajne w polskim porządku prawnym. Warszawa: Wyd. Poltext.

(2020). Dziesięć lat po wielkiej powodzi. Inwestycje i działania Wód Polskich. Pobrane z: https://www.wody.gov.pl/aktualnosci/1086-dziesiec-lat-po-wielkiej-powodzi.

Prokop, K. (2005). Stany nadzwyczajne w Konstytucji Rzeczypospolitej Polskiej z dnia 2 kwietnia 1997 r. Białystok: Wyd. Temida 2.

(2019). Prace Sejmu. Pobrane z: http://www.sejm.gov.pl/Sejm8.nsf/page.xsp/prace_ sejmu.

(2007). Odpowiedź sekretarza stanu w Ministerstwie Rolnictwa i Rozwoju Wsi - z upoważnienia ministra - na zapytanie $n r 2715 \mathrm{w}$ sprawie sytuacji $w$ sadownictwie zwiazanej z gwaltownym spadkiem temperatur. Pobrane z: https://orka2.sejm.gov.pl/ IZ5.nsf/2df80fe4116b3f62c12573be003cb40d/c55e836bc90dd153c12574830043ddc1?OpenDocument.

(2010). Interpelacja nr 16330 do prezesa Rady Ministrów w sprawie działań i zaniechań rzadu w zakresie zarzadzania kryzysowego podczas klęski powodzi. Pobrane z: http://orka2.sejm.gov.pl/IZ6.nsf/2df80fe4116b3f62c12573be003cb40d/e1bdbfc544518e2cc125775400418f65?OpenDocument.

(2010). Odpowiedź sekretarza stanu w Ministerstwie Spraw Wewnętrznych i Administracji - z upoważnienia prezesa Rady Ministrów - na interpelację nr 16330 w sprawie działań i zaniechań rzadu w zakresie zarzadzania kryzysowego podczas klęski powodzi. Pobrane z: http://orka2.sejm.gov.pl/IZ6.nsf/main/355240C6.

(2014). Odpowiedź ministra rolnictwa i rozwoju wsi - z upoważnienia prezesa Rady Ministrów - na interpelację nr 29624 w sprawie braku reakcji rzadu na wniosek rolników oraz wojewody podlaskiego odnośnie do wprowadzenia przez Radę Ministrów stanu klęski żywiołowej na wskazanych obszarach woj. podlaskiego w związku $z$ afrykańskim pomorem świń i szkodami wyrzadzonymi przez zwierzynę towna oraz wypłaty należnych rekompensat dla rolników. Pobrane z: http://www.sejm.gov.pl/ sejm7.nsf/interpelacjaTresc.xsp?documentId=81FE28AD9CAFEDACC1257DEE003C5FB6\&view=10.

(2015). Odpowiedź na interpelację nr 34515 w sprawie suszy i jej skutków w rolnictwie. Pobrane z: http://www.sejm.gov.pl/sejm7.nsf/interpelacjaTresc.xsp?documentI$\mathrm{d}=$ B594EB513AA15277C1257EED004C4C5A\&view=1o. 
(2015). Odpowiedź na interpelację nr 34379 w sprawie pomocy rolnikom poszkodowanym przez utrzymująca się suszę. Pobrane z: http://www.sejm.gov.pl/sejm7.nsf/InterpelacjaTresc.xsp?key=56369F94.

(2018). Odpowiedź na interpelację nr $22820 \mathrm{w}$ sprawie ogłoszenia stanu klęski żywiołowej z powodu suszy. Pobrane z: http://www.sejm.gov.pl/sejm8.nsf/interpelacja. $\mathrm{xsp}$ ?typ=INT\&nr=22820.

Stankiewicz, A., Śmiłowicz, P. (2010). Kaczyński czy Komorowski, czyli komu pomoże wielka woda. Pobrane z: https://www.newsweek.pl/polska/wybory-prezydenckie2010-kto-dzieki-powodzi-wygra-wybory-2010/83m21wb.

Szczepański, D. (2016). Subcarpathia in the perspective of parliamentary election. Political Preferences, 13, 165-179. DOI: 10.6084/m9.figshare.4284665.

Wodzikowski, C. (2019). Zagrożenia ekologiczne społeczności lokalnych. Straty w województwie pomorskim, po nawałnicy z dnia 11/12 sierpnia 2017 r. Studia Ecologiae et Bioethicae, 17(1), 49-55. DOI: 10.21697/seb.2019.17.1.05. 